\title{
Planning of the Administration Undergraduate Course: Case Study at the Federal University of Sao Carlos - UFSCar/NSC-LS
}

\author{
Edenis Cesar de Oliveira, Nilton Cezar Carraro \\ Natural Sciences Center, Federal University of Sao Carlos (UFSCar/NSC-LS), Sao Paulo, Brazil
}

Email address:

edeniscesar@ufscar.br (E. C. de Oliveira),nilton.carraro@ufscar.br (N. C. Carraro)

\section{To cite this article:}

Edenis Cesar de Oliveira, Nilton Cezar Carraro. Planning of the Administration Undergraduate Course: Case Study at the Federal University of Sao Carlos - UFSCar/NSC-LS. Science Journal of Business and Management. Vol. 7, No. 5, 2019, pp. 107-119.

doi: $10.11648 /$ j.sjbm.20190705.12

Received: September 10, 2019; Accepted: September 27, 2019; Published: October 10, 2019

\begin{abstract}
This study aims to investigate the critical perception of PCP's UFSCar Management Course at the Natural Sciences Center, from the perspective of the actors most directly involved with this instrument. Based on the assumptions of the interpretative paradigm, we used a qualitative and exploratory research model. As a data collection instrument, we employed document analysis, questionnaires and participant observation. The main results show that, in general, Educational Program Planning (PPE) translates into an important tool for academic management. However, they revealed the need for greater emphasis on the dissemination of this instrument in the academic community. Nevertheless, the functionality and consolidation of the EPP's proposed methodology requires from all stakeholders an academic management effort with clear objectives, guided by a practical agenda built and practiced by many hands. Nevertheless, it is necessary to update this instrument frequently, especially with regard to nomenclatures - an emblematic fact that the case of "Strategic Planning" changes to "Business Strategy" or "Company Strategy" - and the respective disciplines, always considering the demands and profiles of the market for which the student is being prepared. In short, academic management, seen in this light, needs a redesign of its implementation processes, especially with regard to the control and construction of formal channels to measure the results of the implemented model, thus generating conditions that feed the system and constantly improve it.
\end{abstract}

Keywords: Business Administration, Educational Program Planning, UFSCar, Bachelor Degree, Academic Management

\section{Introduction}

The importance of education in citizen education has been discussed since ancient times. In the last decades, the subject has occupied the most diverse arenas of debate. Whether in the context of public policies, government policies, business and third sector organizations, society in general, the issue has been debated to the point of exhaustion, especially in the most critical dimensions of models that are considered outdated, the adoption of new approaches to teaching that are more contextualized, or even the insertion of new technologies as innovation tools in the context of the teaching-learning binomial, or, as Silva [1] points out, in the process of "teaching-learning".

Education is an important subsystem of the social sphere, allowing the individual to acquire systematized knowledge, develop skills and competencies for the purpose of making effective use of them in their future professional activity [2].

There seems to be no doubt that there is a consensual relationship about the importance of this factor as a strategic contributor to a nation's development. The speed and speed of social, political, economic and cultural change are becoming constant in these new times. It is the "age of uncertainty" postulated by Galbraith [3] or the "age of discontinuity" [4].

Colossi et al. [5] point out that the meaning of the "new millennium" identifies with the global transformations that characterize the so-called modern world. Factors such as computerization, globalization and the knowledge society are some of the factors that put pressure on the status quo of today's life.

In this scenario, education is becoming increasingly 
strategic, given the need to respond to the most diverse facets of social demands directly influenced by the mutations/alternations/complexities/differentiations of macroenvironmental variables.

Seen in this way, it can be said that we are positioned in the face of a new epistemology of knowledge, which defines research perspectives centered not only on the material conception of educational facts, but, above all, on the symbolic markets that describe, interpret and place them in a given space/time [6].

Thus, the study efforts on the curriculum, as well as curriculum theory, mainly focusing on the teaching, organization and legitimation processes, besides the transmission of contents, constitute a field that contributes significantly to the awakening of critical-reflexive postures with regard to the relation locus of teaching, culture and its consequences [7].

This article is structured from this brief introduction, also containing as a subsection the establishment of the research problem and the central objective of the work. Section 2 discusses the main theoretical frameworks that support the research. In section 3 , the methodological procedures are presented, followed by the analysis and discussion of the results (section 4) and, finally, in section 5, the conclusion of the work.

Given the above, the research question that arises is what is the perception about the Pedagogical Course Project (PCP) of the Administration Course of the Federal University of Sao Carlos (UFSCar) Science Natural Center in the view of its multiple actors?

To solve this problem, the present study aimed to investigate the perception of the PCP of the UFSCar Natural Science Center management course, from the perspective of the actors most directly involved with this instrument.

It is noted that in the literature the terms Pedagogical Course Project (PCP) and Pedagogical Political Project (PPP) are found, both having the same meaning. Thus, in this paper, the two terms may be cited interchangeably, keeping the original nomenclature used in the adopted theoretical framework.

\section{A Conceptual Framework}

This section presents a literature review that is minimal enough to provide theoretical support to the research.

Market changes require organizations to take critical stances to respond to environmental demands, prompting them to make continued efforts to remain competitive in this scenario [8].

Transposition into a learning model that is beyond that traditionally based on the simple acquisition of skills to perform the tasks required by each corporate function becomes inevitable and urgent [9].

According to Gonczi [10], there is an urgent need to train people, enabling them to perform tasks with higher levels of competence, a situation very adverse from that emphasized in a mass production context. Such an assertion can also be seen from the perspective of the teachers themselves, as concluded by Nunes and Patrus-Pena [11], stating that the formation of the university professor is a challenge that is at the center of the discussion about the formative process for the most part, has no educational background.

For this to occur effectively, changes must be made to the entire "didactic architecture" of training, needs analysis, goal setting, content selection and delineation, methodology, and evaluation process [12] and in a cyclical process, promoting constant reassessment and monitoring.

Ropé and Tanguy [13] propose that competence be inseparable from action, corroborating the statement by Perrenoud [14], for whom competence formation is "inseparable from the formation of knowledge mobilization schemes with real-time discernment at the service of effective action."

The formation of human beings contemplating all their capacities, based on a work that includes the knowledge that integrate society, must be a primary task of education [15]. Ching, Silva and Trentin [16] reiterate that ensuring that classroom knowledge or content is meaningful to the student is tied to the fact that they are not "sliced" into subjects. For these authors, on the one hand, "separating them into disciplines is an operation that has facilitated the acquisition of knowledge, but on the other hand has often deprived this knowledge of its meaning" [16].

Undeniably, some limitations will be present in the implementation of competence training [17]. Nevertheless, Gonczi [10] states that the process of change takes a great deal of time, which tends to aggravate the discouragement and the consequent demobilization of the actors involved.

Corroborating this understanding, Rué [18] points out that the introduction of a new educational conception requires investment of time, both quantitative and qualitative, among other resources, besides the involvement of all actors in a process of reflection on the phenomenon, the results achieved (or not), constant monitoring and reformulation of new procedures as premises for replanning. The author also draws attention to the complexity of the pedagogical conception, as well as the application in the classroom and the way of evaluating the students.

This whole theoretical framework is deliberately established in the Pedagogical Course Plan, which brings together the main guidelines for course management.

Silva [19] argues that historizing curricular documents as objects and sources requires that the conditions of their production be taken into account, that is, that the content itself is not dissociated from the place occupied by this form in the history of education and curriculum. Thus, like any other type of printed documentary record, curriculum documents "embody" knowledge [20].

The assumptions of this study are supported by the theoretical conceptions of Silva [19], as systematized in Table 1. 
Table 1. Theoretical conceptions adopted as guidelines in the study.

Excerption
"[...] in discourses about school education and about school, it has been common to point out that curriculum is not an innocent and
neutral element of disinterested transmission of social knowledge...".
"In the curriculum field", the versatility, competence and practical importance of knowledge have served to justify a new
curriculum that is validated by the values of emancipation, integration, social relevance and updating of knowledge. It is in the
framework of these ideas that we are conceiving knowledge, schools and their professionals as active agents in the configuration of
processes that make the curriculum richer, more rigorous, more reflective".
"[...] curriculum documents produce a specific culture, with organized and selected types of symbols, which are directly related to
the types of students and how they make use of this kind of knowledge that is socially stratified and that represents conflicts. Based
on these conflicts, it is possible to understand the economic and cultural functions of educational institutions."
"[...] These documents would not be able to realize all the insufficiencies of society in the face of different groups and their
educational needs. But it is in the impossibilities of building curricular differentiation that we find the realization of the formal (and
ideal) concept of equal opportunities through a single curriculum for all students."

Source: Prepared by the author based on Silva [19].

The systematized guidelines in Table 1 support the broader scope of the study, since they show the reading perspective of the Pedagogical Course Project (PCP), object of this study, based on the proposal of Fischer, Waiandt and Fonseca [21], reiterating that one of the main characteristics of research directed at the history of the curriculum is the historicalsocial character and, therefore, their research emphasizes the studies of oral sources added to documents to understand the construction of knowledge.

The Bachelor of Business Administration Course with Training Line in Agroindustrial Systems, at Natural Science Center of UFSCar, lasts four years and aims to train professionals who can contribute in the traditional areas of performance of the administrator, following the guidance of Resolution CNE/CES 4/2005, in Articles 3 and 4 [22], in addition to incorporating a relevant set of skills/competences and knowledge for graduates and other aspects of teaching and learning that highlight organizational, institutional and technological specificities of the systems' agribusiness at national and international levels.

The concept of competence arises from the need to meet a demand from the professional field, later migrating to the educational area [14]. As explained by Zabala and Arnau [23], this diffusion occurred sharply, causing favorable and contrary opinions regarding the use of skills and competences in educational institutions, since it was used to overcome circumscribed teaching to memorization of contents.

Garcia [24] also understands the concept analogous, postulating that it enables the subject to face a situation through the mobilization of knowledge. Competence, therefore, would be the ability to use more than one resource to solve something in an innovative, creative and timely manner.

The institution fulfills an important social and educational function focused on the current demands of the labor market and society. In this sense, the university's fundamental commitment is to train a professional with a set of competences and skills, as systematized in Table 2.

Table 2. Profile of Business Administration Graduate - UFSCar/Center for Natural Sciences - CCN.

\section{Expected Skills/Skills}

Administer public and private organizations, with management capacity adapted to the peculiarities and heterogeneity of agroindustrial systems

A (whether based on family farming or corporate agriculture) in Brazil and around the world, which will help to overcome the challenges posed to food production, the overcoming of hunger and the development of new standards for food regulation, production, distribution and consumption. Acting within different agroindustrial production models, linking scientific knowledge to sustainable development, professional practice and social

B progress, in order to allow critical and creative action in the identification and resolution of food production problems and the search for food and nutritional security.

C To evaluate economic, political, social and environmental impacts on agroindustrial production and the construction of biodiversity conservation processes in agroindustrial systems.

D Integrate different types of knowledge and knowledge areas to develop your administrative skills. To act in a participatory and interactive way in global and local agri-food and agro-industrial systems through the development of ways of thinking, attitudes, values and skills based on the principles of respect for different forms of production, flora and fauna; conservation and/or restoration of soil, air and water quality; rational, integrated and sustainable technological use of the environment; the use of reflective, critical and creative thinking that enables it to understand and translate the needs of individuals, social groups and political actors.

Develop knowledge, leadership and specific strategies for the management of agroindustrial operations, social organization, food marketing,

F finances improvements in agroindustrial systems and food production, forecasting capacity of macroeconomic and microeconomics environments, and capacity for developing public and agroindustrial policies for heterogeneous regions.

G Manage with a degree of motivation and ability to think independently (learn to learn), with a solid understanding of the fundamentals of management and communication skills.

$\mathrm{H} \quad$ Manage projects in general and specifically, agroindustrial, agricultural, territorial development, public policy, prospection and development of

$\mathrm{H} \quad$ agroindustrial markets and localized agri-food systems.

I Carry out rural extension activities, consolidation of productive chains and agroindustrial and agri-food cooperation networks.

Source: Paulillo et al. [25]. 
In order to substantiate this proposed egress profile defined for the Bachelor of Business Administration Course at the Agroindustrial Systems Training Line, at the UFSCar's Natural Science Center, students will be able to acquire general and specific knowledge of the course. Administration course when developing each of the four (4) thematic axes for training in agroindustrial system, as well as the timely development of knowledge and skills involving personal qualities, communication and expression, economics and management, production technologies, quantitative methods and information systems [25].

The pedagogical principles that support the curricular structure of the Bachelor of Management Course, focus of this study, are as follows.

a) Curricular organization in annual periods.

b) Distribution of contents in the following thematic axes:

1) Sustainable Territorial Development and Public Policy

2) Finance and Economy

3) Marketing

4) Administration of Agroindustrial Operations

a) Non-fragmented content: the thematic axes will be dealt with in full, not being broken down into disciplines.

b) Basic contents continuously taken up and deepened in the thematic axes over the years, according to the needs posing by the knowledge worked in each axis/year.

c) Professional and basic training combined since the beginning of the course.

d) Classes distributed throughout the week, the academic calendar of the university.

The proposition of the pedagogical principles highlights some innovative elements such as the distribution of the contents in thematic axes, the integration of the axes, besides the professional and basic formation since the beginning of the course. The process of resuming the contents with different levels of deepening points to a spiral method.
Veiga [26] points out that innovation and pedagogical political design only make sense if the focus is on improving the quality of public education so that everyone learns more and better. This concern is evident in the three central objectives of education based on the person, citizenship and work.

Developing the student, preparing him/her for the exercise of citizenship and work, represents, above all, contribute to the construction of a subject that masters knowledge, is endowed with a set of attitudes necessary to be part of a political system, besides participating of the production processes of survival, developing personally and socially [26]. To this end, the importance of curricular adaptation to the demands arising from the needs of current applicants is stressed [27].

Fischer [28] proposes that management education, based on the historiography of education, be classified into four levels for research purposes:

a) The life of teachers who built, from their performance as teachers, thematic fields, ways of teaching, organizations and institutions.

b) Teaching legacies, or the history of curricula, programs, and ways of teaching and learning.

c) The history of disciplines or the history of the evolution of thinking in business.

d) The history of business education institutions in Brazil. However, whatever the level chosen, the others may be contemplated as an approach perspective. In other words, there is an inevitable juxtaposition of these levels of analysis and imminent convergence between teachers, teaching designs, educational institutions, and content to be taught [28].

Having established the pedagogical principles, the broad knowledge (mesocontents) that make up each of the thematic axes was defined, as presented in Table 3 .

Table 3. Thematic Axes and their Mesocontent Respectives.

\begin{tabular}{|c|c|c|c|c|}
\hline \multirow[b]{2}{*}{ Profiles } & \multicolumn{4}{|l|}{ Thematic Axes } \\
\hline & $\begin{array}{l}\text { Sustainable Territorial Development } \\
\text { and Public Policy (STDPP) }\end{array}$ & Finance and Economics (FE) & Commercialization (COM) & $\begin{array}{l}\text { Agribusiness Operations } \\
\text { Administration (AOA) }\end{array}$ \\
\hline \multirow{4}{*}{1} & $\begin{array}{l}\text { Approaches to Sustainability and } \\
\text { Business Paradigms }\end{array}$ & $\begin{array}{l}\text { Introduction to Economic } \\
\text { Thought Classical } \\
\text { Macroeconomics }\end{array}$ & Introduction to Marketing & $\begin{array}{l}\text { Fundamentals of } \\
\text { Management }\end{array}$ \\
\hline & $\begin{array}{l}\text { Sustainability Management: } \\
\text { Innovation, Operations, Relationship } \\
\text { and Responsibility, Socioenvironmental }\end{array}$ & $\begin{array}{l}\text { Keynesian and Neokeynesian } \\
\text { Macroeconomics }\end{array}$ & $\begin{array}{l}\text { International Trade and } \\
\text { Export Policies }\end{array}$ & Organizational Theory \\
\hline & Rural Research and Extension & Political Economy & Commercial Law & $\begin{array}{l}\text { Agricultural Production } \\
\text { Factors }\end{array}$ \\
\hline & $\begin{array}{l}\text { Introduction to Systems } \\
\text { Agroindustrial } \\
\text { Applied Sociology } \\
\text { Administration }\end{array}$ & $\begin{array}{l}\text { Mathematics Applied to } \\
\text { Administration }\end{array}$ & & Organizational Psychology \\
\hline \multirow{4}{*}{2} & Rural Development and Family Farming & Industrial Organization & Consumer Behavior & People management \\
\hline & Agricultural Policies & Statistic & $\begin{array}{l}\text { Agriculture and Agribusiness } \\
\text { Marketing }\end{array}$ & $\begin{array}{l}\text { Position Management, } \\
\text { Compensation and Careers }\end{array}$ \\
\hline & Environmental Management & Microeconomics & & $\begin{array}{l}\text { Agroindustrial Process } \\
\text { Technologies }\end{array}$ \\
\hline & $\begin{array}{l}\text { Rural Sociology } \\
\text { Legislation and Environmental Law }\end{array}$ & Financial Mathematics and & Marketing of Agroindustrial & $\begin{array}{l}\text { Production Management } \\
\text { Quality management }\end{array}$ \\
\hline
\end{tabular}




\begin{tabular}{lllll}
\hline \multirow{2}{*}{ Profiles } & Thematic Axes & & \\
\cline { 2 - 5 } & $\begin{array}{l}\text { Sustainable Territorial Development } \\
\text { and Public Policy (STDPP) }\end{array}$ & Finance and Economics (FE) & Commercialization (COM) & $\begin{array}{l}\text { Agribusiness Operations } \\
\text { Administration (AOA) }\end{array}$ \\
\hline & & Investment Analysis & Products & Rural Company \\
& Associativism and Cooperativism & Management Accounting & Distribution Channels & $\begin{array}{l}\text { Management } \\
\text { Water Resources Planning and }\end{array}$ \\
Management & Agroindustrial Costs & & Pupply Chain Management \\
& & & Panagect management \\
Regional Development and Food & Financial management & Futures Markets and & Systems \\
Security & Agricultural Options & Strategic and Business \\
Energy Resource Management & Planning and Budget & Tax Law & Planning \\
& Company Law & & Scientific methodology \\
& Development of New Business & & Operational Research \\
\hline
\end{tabular}

Source: Adapted from Paulillo et al. [25].

The development of vertical and horizontal integration occurs through the contents and, to this end, the work of teachers assumes a highly strategic character in this process, especially by requiring a high level of integration and cooperation. This integration is based on themes, questions or problems related to the contents coming from the thematic axes, which are defined by the faculty responsible for the contents of the thematic axes each year, including the moments of the integrative evaluation. Figure 1 graphically systematizes this relationship from the student education profile.

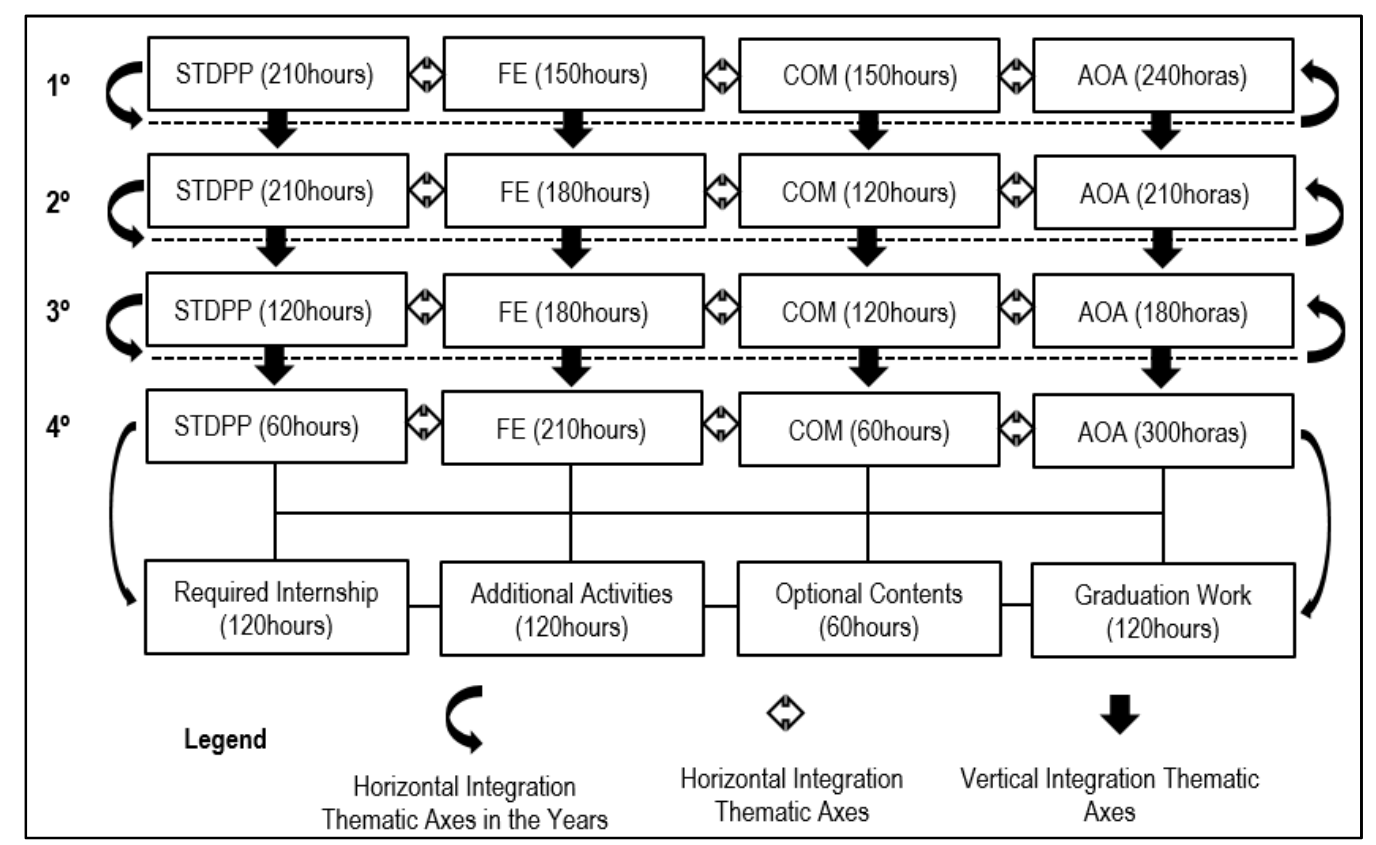

Source: Adapted by the author based on Paulillo et al. [25].

Figure 1. Graphic Representation of Training Profile.

Teachers, in assuming the practice of teaching by competencies, inevitably appropriate responsibilities in choosing their social practices. In this way, they change their own views about culture and society, especially in the process of knowledge construction [14]. However, there is a risk that some will not opt for this approach by continuing to undertake their teacher model in a segregated and disciplinary manner.

This proposal assumes that the learner learns in different ways, requiring from the teacher the ability to perceive and meet this diversity within the classroom. Therefore, it is not enough for the student to have contact with the contents for learning to occur; It is necessary for him to relate his previous knowledge to the new, and to use his knowledge schemes to analyze and apprehend them Zabala [29].

Perrenoud [14] understands that working together with disciplines contributes to thinking problems from epistemological conceptions, both in the method, in the relationship between research and knowledge, as in the valorization of writing and in the potential transverses.

This methodological conception, in practice, requires a high effort from the entire academic community, especially teachers, 
demanding an additional agenda of formal or informal meeting to discuss, align their plans, projects, and the daily classes themselves. How do you consider Silva and Felicetti [30]:

Problem situations are a challenge in the development of skills and competences as they require a higher demand for work. For the teacher it is necessary to think about each project, to predict the duration, to observe, to evaluate differently from the usual and more than that, it is necessary to know both the contents and the connection between them, either in the subject or in different subjects, such as the ones. students. Knowing the student means understanding if he already knows, has learned, what he has learned, which competency he has already achieved, which is still being built and which needs to be worked on. The student must establish other relationships, go beyond exercise and repetition, make decisions, analyze the context, separate and articulate parts of the problem in search of solutions.

Additionally, it is known that, over time, the ability to teach as a priority assignment of the teacher has been influenced by the improvement of learning modes, the cognitive aspect, as well as values, attitudes and skills [31]. An emblematic example is the steep increase in students' ability to access information via online content [32]; This capacity becomes even more relevant considering the changing world scenario, inexorably influenced by the revolutionary effects of new technologies [33].

There is no doubt that this methodological design requires additional effort and, perhaps, even paradigmatic changes in conceptions hitherto seen as appropriate. However, the fruits that are expected to reap constitute the "driving spring" to leverage the necessary actions so that, in fact, all this gear can work to its satisfaction.

International studies carried out in several countries (Canada, Australia, Finland, Sweden, Denmark, England, Scotland and the United States) show that the use of integrated teaching models is a real challenge for all involved, especially in the aggregation of knowledge, competences and skills [34], after all, as Perrenoud [35] asserts, "there is no competence without knowing".

The methodological treatment of the Management Course with Training Line in Agroindustrial Systems of the Center of Natural Sciences (CNS/UFSCar) is based on the proposition of a different methodology, from the treatment of conceptual, procedural and attitudinal contents [29].

These elements that underlie the methodological treatment are presented in Table 4.

Table 4. Fundamental elements of methodological treatment.

\begin{tabular}{ll}
\hline & Elements \\
\hline 1 & Teacher as a mediator of the teacher-student-knowledge relationship Maximizing student autonomy in the pursuit of knowledge \\
2 & Validity of teaching proved by its justification in learning, so as to understand that there will have been no teaching if there is no learning \\
3 & Vertical integration provided by deepening and resuming, when necessary, the main contents in each thematic axis over the four years \\
4 & Horizontal integration between the contents of each axis/year, allowing the integrated view of the contents of the different thematic axes \\
5 & $\begin{array}{l}\text { Content integration in the horizontal and vertical planes promoted/guided by teachers, not under the sole responsibility of the students } \\
6\end{array}$ \\
$\begin{array}{l}\text { Collaborative work of teachers in order to jointly develop the annual didactic planning, integrating the contents in each of the thematic axes, as well } \\
7\end{array}$ & Maximizing student autonomy in the pursuit of knowledge \\
\hline
\end{tabular}

Source: Prepared by the author based on Paulillo et al. [25].

There is a need to change the same content "Strategic and Business Planning" inserted in the fourth profile to "Strategic Management". This is not a simple change of nomenclature, but part of a broader understanding where "strategic planning" is the instrument that results from strategy design in the context of Strategic Management.

Bertero [36] argues that strategic planning was restricted to analyzing the strengths and weaknesses of an organization, and later incorporated the planning and management of eventual changes in the organizational environment. It went into crisis due to the increasing unpredictability of the business environment, which required a more dynamic and integrated stance. It was in this context that the Strategic Administration gained space, being responsible for the development and implementation of the strategy.

Quality education that seeks to educate citizens capable of critically interfering with reality in order to transform it must necessarily contemplate the development of capacities that enable adaptations to the complex conditions and alternatives of the contemporary working world, as well as to cope with the rapidity of production and in the circulation of information and the formation of new knowledge, which has inexorably become overwhelming and growing. Thus, school education should enable students to develop competence and professional awareness, but not be restricted to teaching skills immediately demanded by the labor market [37].

International studies suggest that the skills and abilities that prospective employers want from business school graduates change as the business environment changes [38].

Therefore, as proposed by the National Curriculum Parameters (NCP), it is essential that, in the teaching and learning process, the learning of methodologies capable of prioritizing the construction of verification strategies and hypothesis verification in the construction of knowledge, the construction of argumentation capable of controlling the results of this process, the development of the critical mind capable of favoring creativity, the understanding of the limits and logical reaches of the proposed explanations [37].

In addition, a teaching dynamic must be considered that contributes not only to the discovery of the potentialities of individual work, but also and, above all, to collective and cooperative work. Evidently, this implies stimulating the subject's autonomy, developing the feeling of security in relation to his own abilities, interacting in an organic and 
integrated way in a teamwork and, therefore, being able to act in more complex and differentiated levels of dialogue.

\section{Methodology}

This study is based on the assumptions of the interpretative paradigm, using a qualitative model [39], since "such models try to incorporate judgments or subjective factors in predictions. Expert opinions, individual experiences, judgments and other subjective factors can be considered." As for its purpose, this research is classified as applied, since it can "contribute to the expansion of scientific knowledge and suggest new questions to be disclosed" [40]. Within this scope, some premises of the experimental method were used, considering that it consists of a "systematic work [...]" that can contribute to the "improvement of new systems and services" [40]. According to Brownell [41], this method has been low in popularity or even underused in management research.

Regarding the more general objectives, the research is classified as exploratory, which aimed to provide greater familiarity with the researched problem [42]; and descriptive, since it aimed to describe the main characteristics of the object of study. From the point of view of approaching the problem, the research is classified as qualitative [43-46]. Finally, regarding the technical procedures, it is classified as a case study [47-51].

Regarding data collection instruments, documentary research $[52,40]$ was used primarily with reading and thorough analysis of the Pedagogical Project of the Management Course with Training Line in UFSCar - Natural Sciences Center.

The execution of the first stage of data collection (documentary research) provided greater robustness in the elaboration of the questionnaire. The instrument contained 13 (thirteen) questions of which 12 (twelve) were ordered in an Itemized Scale [53, 54], also classified as a Metric Scale, called the Likert Scale [55] and one (1) open question (justification). The application followed the standards of a semi-structured research script [56-58], given that this collection instrument was administered by the interviewer $[59,60]$. Thus, considering that all interviews involve the interaction between the interviewer and the interviewee, formal structuring carefully guides this interaction [61, 62].

Therefore, the validation of the questionnaire was performed by pretesting and determining the method by which the tool would be administered, as proposed by Hair Jr. et al. [55].

In order to obtain information that might not be detected by the other methods, we also adopted participative observation along the lines proposed by Bechker [63], who understands observation as a solution to the study of complex phenomena institutionalized, when descriptive and exploratory analyzes are intended to be carried out or even when the objective is to infer about a phenomenon that refers to certain regularities, subject to generalizations. In this sense, the researcher, in the role of vice-coordinator of the course, effectively participates in the meetings of the Structuring Teacher Nucleus (STN), considered a collegiate body in educational management [64] and the Management Course Coordinating Board (MCCB-Adm).

Regarding the choice of actors, it was decided to consult those most directly involved with the elaboration, implementation and current execution of the PCP. Table 5 presents the actors and their respective positions.

Table 5. Interviewed actors and their positions and codes adopted in the study.

\begin{tabular}{lll}
\hline Actors & Positions & Codes \\
\hline \multirow{2}{*}{1} & Academic Board of the Center for Natural & ABCNS \\
2 & Sciences - UFSCar/CCN & BCC \\
3 & Business Course Coordination & APC \\
4 & Academic-Pedagogical Coordination & ATSAC \\
& Administrative Technician (Secretariat of the & \\
5 & Administration Course) & SRGCCC \\
\hline
\end{tabular}

It is noteworthy that the actor DACCN, currently occupying the position "Academic Board", was an integral member of the PCP preparation committee of the course under study.

The next section presents the analysis of the main results found in the research using the proposed methodology.

\section{Results and Discussion}

The National Curriculum Guidelines (NCG) of the Bachelor of Management Course (Resolution No. 4/2005), in its Art. 5, directs that the Bachelor of Management courses must include, in their pedagogical projects, as well as in their curricular organization, contents that reveal interrelationships with the national and international reality, according to a historical and contextualized perspective of its applicability within organizations and through the use of innovative technologies.

Table 6 shows the correspondence between the provisions of the NCG and the proposed contents in each thematic axis.

Table 6. Correspondence between the provisions in dcn and the proposed contents in the thematic axes. Source: Prepared by the author based on Paulillo et al. $[25]$.

\begin{tabular}{llll}
\hline Basic Training Contents & & Workload \\
\hline Basic Content & Axis & 30 & Credits \\
\hline Applied Sociology of Administration & STDPP & 30 & 2 \\
Introduction to Economic Thinking & FE & 30 & 2 \\
Classical Macroeconomics & FE & 30 & 2 \\
Keynesian and Neokeynesian Macroeconomics & FE & 15 & 1 \\
Political Economy & FE & 30 & 2 \\
Commercial Law & COM & 1 \\
\hline
\end{tabular}




\begin{tabular}{|c|c|c|c|}
\hline \multicolumn{4}{|l|}{ Basic Training Contents } \\
\hline Basic Content & Axis & Workload & Credits \\
\hline Rural Sociology & STDPP & 30 & 2 \\
\hline Industrial Organization & FE & 60 & 4 \\
\hline Microeconomics & FE & 60 & 4 \\
\hline Legislation and Environmental Law & STDPP & 30 & 2 \\
\hline Company Law & $\mathrm{FE}$ & 30 & 2 \\
\hline Tax Law & COM & 30 & 2 \\
\hline Scientific Methodology & $\mathrm{AOA}$ & 60 & 4 \\
\hline Regional Development and Food Security & STDPP & 30 & 2 \\
\hline Rural Research and Extension & STDPP & 60 & 4 \\
\hline Introduction to Agroindustrial Systems & STDPP & 60 & 4 \\
\hline Rural Development and Family Farming & STDPP & 60 & 4 \\
\hline Organizational Psychology & $\mathrm{AOA}$ & 60 & 4 \\
\hline Consumer Behavior & $\mathrm{COM}$ & 60 & 4 \\
\hline Total & & 780 & 52 \\
\hline \multicolumn{4}{|l|}{ Vocational Training Content } \\
\hline \multicolumn{4}{|l|}{ Professional Content } \\
\hline Introduction to Marketing & $\mathrm{COM}$ & 60 & 4 \\
\hline International Trade and Export Policies & $\mathrm{COM}$ & 60 & 4 \\
\hline Fundamentals of Management & $\mathrm{AOA}$ & 60 & 4 \\
\hline Organizational Theory & $\mathrm{AOA}$ & 60 & 4 \\
\hline Environmental Management & STDPP & 60 & 4 \\
\hline Agriculture and Agribusiness Marketing & $\mathrm{COM}$ & 60 & 4 \\
\hline Production Management & $\mathrm{AOA}$ & 60 & 4 \\
\hline Marketing of Agroindustrial Products & $\mathrm{COM}$ & 60 & 4 \\
\hline Agroindustrial Costs & $\mathrm{FE}$ & 60 & 4 \\
\hline Distribution Channels & $\mathrm{COM}$ & 60 & 4 \\
\hline Quality Management & $\mathrm{AOA}$ & 30 & 2 \\
\hline Supply Chain Management & $\mathrm{AOA}$ & 60 & 4 \\
\hline Project Management & $\mathrm{AOA}$ & 30 & 2 \\
\hline Sustainability Management & STDPP & 30 & 2 \\
\hline Financial Management & FE & 60 & 4 \\
\hline Planning and Budget & FE & 30 & 2 \\
\hline Management Information Systems & $\mathrm{AOA}$ & 60 & 4 \\
\hline Strategic and Business Planning & $\mathrm{AOA}$ & 60 & 4 \\
\hline People Management & $\mathrm{AOA}$ & 60 & 4 \\
\hline Position Management, Compensation and Careers & $\mathrm{AOA}$ & 30 & 2 \\
\hline Rural Company Management & $\mathrm{AOA}$ & 60 & 4 \\
\hline Management Accounting & FE & 60 & 4 \\
\hline Futures Markets and Agricultural Options & $\mathrm{COM}$ & 30 & 2 \\
\hline Total & & 1200 & 80 \\
\hline \multicolumn{4}{|l|}{ Quantitative Studies and their Technologies } \\
\hline \multicolumn{4}{|l|}{ Specific Content } \\
\hline Mathematics Applied to Administration & $\mathrm{FE}$ & 45 & 3 \\
\hline Statistic & FE & 60 & 4 \\
\hline Financial Mathematics and Investment Analysis & FE & 60 & 4 \\
\hline Agricultural Production Factors & $\mathrm{AOA}$ & 60 & 4 \\
\hline Agroindustrial Process Technologies & $\mathrm{AOA}$ & 60 & 4 \\
\hline Operational Research & $\mathrm{AOA}$ & 60 & 4 \\
\hline Game Theory and Business Policy & FE & 60 & 4 \\
\hline Total & & 420 & 28 \\
\hline
\end{tabular}

It is important to note that in the Administration Course with Training Line in Agroindustrial Systems at UFSCar, Natural Science Center, the traditional nomenclature "disciplines" is not adopted, but "mesocontent", which shows, at first, certain Alignment with the proposal of Ching, Silva and Trentin [16], which emphasize the importance of working the contents in the most integrated way possible, without slicing them into disciplines.

The workload of the four content categories totals 2,700 hours, corresponding to 180 credits. In addition, it should be added to this workload, the values corresponding to Supervised Curricular Internship (120h), Course Completion
Work (120h), Complementary Activities (120h) and Optional Content $(60 \mathrm{~h})$. Table 6 shows that approximately $45 \%$ of the total content workload refers to vocational training content.

The optional contents for the course under study will be built during the first years of its implementation. At a first moment, students will be able to study, according to their interest, the optional contents of the other campus courses, considering the interface between them [25].

It is emphasized as positive factor the performance of the Structuring Teaching Core (STC), as well as the Management Course Coordinating Board (MCCB-Adm), which can be proven through participant observation and documentary 
analysis, especially the reading the minutes of those collegiate. Nevertheless, it is noted that the notes made in the "field diary" meet the conception adopted by Darnton [20].

In this sense, the Structuring Teaching Core (STC) and the Management Course Coordinating Board (MCCB-Adm) become the locus of constructive genesis, notably, from the perspective of teaching work, thematic fields, different and differentiated forms of teaching [28], which, finally, as stated by Kanuka [34], turns out to be a real challenge for all involved, especially in the aggregation of knowledge, skills and ability.

Table 7 summarizes the ordinary and extraordinary official meetings of these two collegiate with agenda points pertinent to the Management Course, presented here, which have taken place to date.

Table 7. UFSCar Management Course Coordinating Council MCCB-Adm and STC Meetings.

\begin{tabular}{llllll}
\hline CCCG-Adm & & & \multicolumn{2}{l}{ Structure Teaching Core } & Meeting \\
\hline Date & Meeting & Category & Date & $1^{\mathrm{a}}$ & Category \\
\hline $17 / 02 / 2016$ & $1^{\mathrm{a}}$ & Ordinária & $09 / 03 / 2016$ & $2^{\mathrm{a}}$ & Ordinária \\
$08 / 03 / 2016$ & $1^{\mathrm{a}}$ & Ordinária & $16 / 03 / 2016$ & $3^{\mathrm{a}}$ & Ordinária \\
$17 / 03 / 2016$ & $2^{\mathrm{a}}$ & Ordinária & $23 / 03 / 2016$ & $4^{\mathrm{a}}$ & Ordinária \\
$23 / 03 / 2016$ & $1^{\mathrm{a}}$ & Extraordinária & $06 / 04 / 2016$ & $5^{\mathrm{a}}$ & Ordinária \\
$30 / 03 / 2016$ & $2^{\mathrm{a}}$ & Extraordinária & $13 / 04 / 2016$ & $6^{\mathrm{a}}$ & Ordinária \\
$13 / 04 / 2016$ & $3^{\mathrm{a}}$ & Ordinária & $26 / 04 / 2016$ & $7^{\mathrm{a}}$ & Ordinária \\
$11 / 05 / 2016$ & $4^{\mathrm{a}}$ & Ordinária & $04 / 05 / 2016$ & $8^{\mathrm{a}}$ & Ordinária \\
$01 / 06 / 2016$ & $3^{\mathrm{a}}$ & Extraordinária & $08 / 06 / 2016$ & & \\
$22 / 06 / 2016$ & $5^{\mathrm{a}}$ & Ordinária & & & \\
\hline
\end{tabular}

The first MCCB-Adm meeting had as its main agenda the official constitution of the Structuring Teaching Core (STC).

The questions contained in the form structured in the Likert Scale model are presented in summation format, as listed in Table 8.

Table 8. Sum of the questionnaire answers.

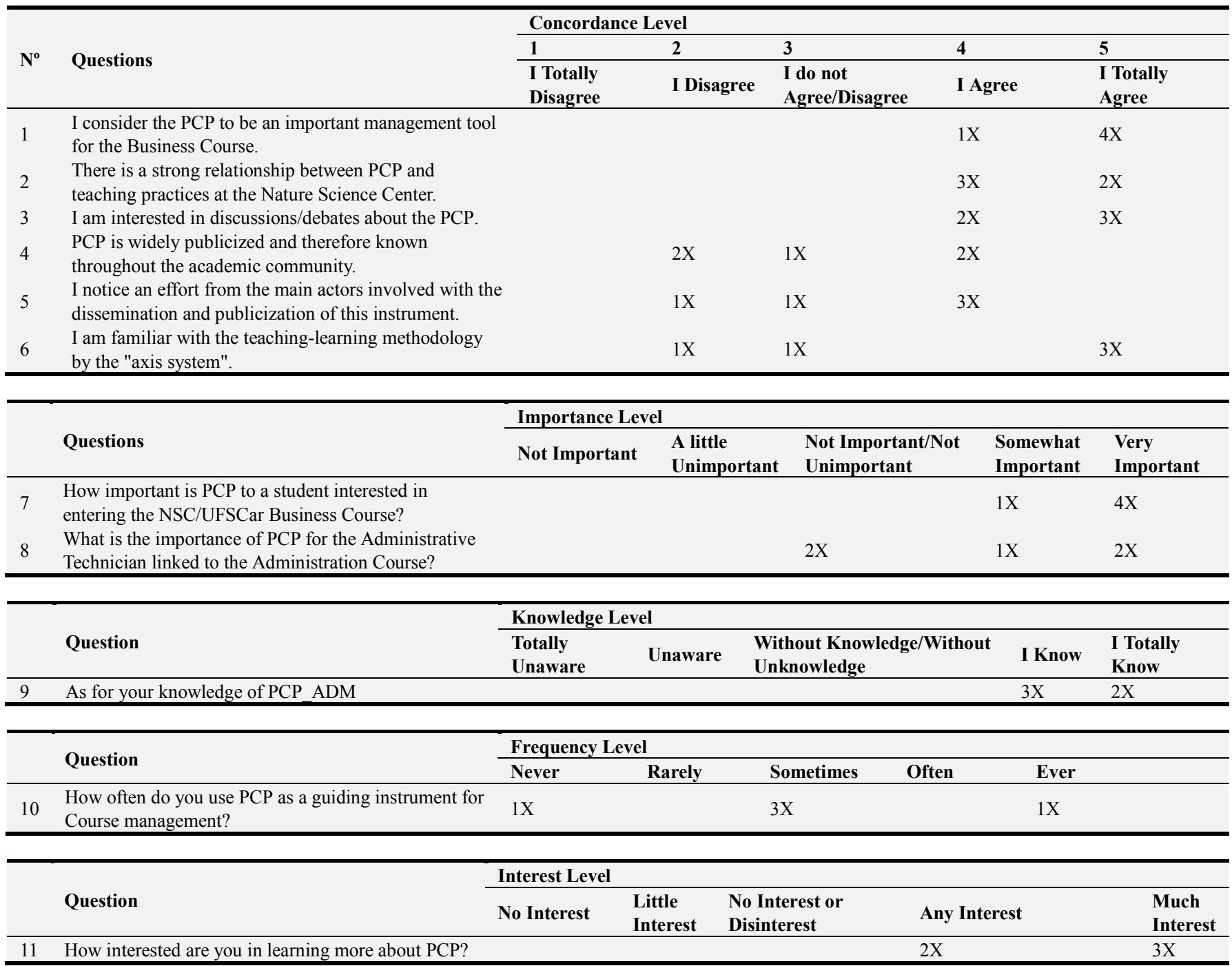


Some points should be highlighted from what is shown in Table 8. Question 4 reflects an unreasonable level of agreement with the PCP disclosure. There are two "concordances" and two "disagreements", which brings the issue to a critical level (one can say "zero level"), plus a "disagreement and nondisagreement", which does not affect anything the result of this question; Therefore, there is a clear signal here that efforts are being made to make this important instrument more effectively reach its main target audience. This question could even be counterbalanced by the next one (question 5), but it cannot be said that this does indeed occur, since there are three "concordances" for a "neutral position" and a "disagreement." Such result is not supported by Fischer, Waiandt and Fonseca [21] proposition, for which the broad understanding of the curriculum is directly linked to the study of documents to understand the construction of knowledge. Along the same lines, Ching, Silva and Trentin [16] assert that: "there is no way to implement a new philosophy [...] without the support and participation of the faculty who will teach in the course".

Regarding the level of knowledge of the PCP, it is observed that, although $60 \%$ of the respondents said they knew and $40 \%$ fully knew the instrument, regarding the level of importance, for these same actors, $40 \%$ consider "neither important nor without importance $20 \%$ "a little important" and the others "very important". Evidently, there is an asymmetry here that deserves a more careful look on the part of managers, especially if one considers the assertions proposed the by the authors [31-33].

As seen, the PCP is a guiding instrument of pedagogical practices in its various dimensions. That said, one can classify as worrying the fact that $60 \%$ of respondents "sometimes" use PCP as a management tool and $20 \%$ "never" use it. It is noteworthy that the actors selected for the research are directly linked to the conception, implementation, execution and coordination of the course in question. This question refers to the assertion of Nunes and Patrus-Pena [11], who draw attention to the lack of pedagogical training in most university course teachers.

The result of the question concerning the degree of knowledge of the Pedagogical Principles contained in PCP is presented in Table 9, by respondent.

Table 9. Degree of knowledge of the multi-actor PCP Pedagogical Principles.

\begin{tabular}{|c|c|c|c|c|c|c|}
\hline \multirow{2}{*}{$\mathbf{N}^{\mathbf{o}}$} & \multirow{2}{*}{ Pedagogical Principles } & \multicolumn{5}{|c|}{ Responding Players } \\
\hline & & DACCN & CCA & CAP & TAADM & DCCCG \\
\hline 1 & Curricular organization in annual periods & 1 & 6 & 1 & 6 & 1 \\
\hline 2 & Distribution of contents in thematic axes & 3 & 2 & 2 & 4 & 5 \\
\hline 3 & $\begin{array}{l}\text { Non-fragmented content: the thematic axes will be treated in full, not } \\
\text { being broken down into disciplines }\end{array}$ & 6 & 4 & 6 & 1 & 4 \\
\hline 4 & $\begin{array}{l}\text { Basic contents continuously taken up and deepened in the thematic axes } \\
\text { over the years, according to the needs posed by the knowledge worked in } \\
\text { each axis/year }\end{array}$ & 5 & 3 & 4 & 2 & 3 \\
\hline 5 & Vocational and basic training combined since the beginning of the course & 4 & 1 & 3 & 3 & 2 \\
\hline 6 & Classes distributed throughout the week/university academic calendar & 2 & 5 & 5 & 5 & 6 \\
\hline
\end{tabular}

Some inferences can be made from the data shown in Table 9. First, however, it is important to point out that the proposed scale was 1 for the lowest level of knowledge and 6 for the highest level of knowledge (no repetition of the numbers).

Thus, for three actors, the first principle is the least known, while for the other two, it is the best known. One of the possible justifications for this asymmetry may be that, although, in practice, the course has annual periodicity, the university's information system is still in a transitional phase, so far remaining semiannually. The second principle presents a result with reasonable heterogeneity. The third principle receives two level four notes of knowledge, while also receiving two notes with maximum degree of knowledge.

The fourth and fifth principles, as they stand, follow the same pattern as the second, with some heterogeneity. The sixth and last principle indicate a certain tendency towards homogeneity, that is, to a higher degree of knowledge on the part of the actors. This result may have been influenced by the actors' own perception in the movement of students/teachers during the academic period, given the fact that the highest degree of knowledge was attributed by the student representative in the Course Coordinating Council.

The participation of the researcher in pedagogical meetings, based on the elaboration of descriptive field reports, attests that there is a consensus among the various actors that the whole process is in the maturation phase. However, when observing the other courses (Agronomic Engineering, Environmental Engineering and Food Engineering) that began in 2014, with a methodology similar to the newly started course under study, it is clear that much has already gone. In turn, it is even more evident that there is a long journey ahead, a fact that seems in line with Gonczi's studies [10].

Especially in this period of consolidation, there is a need for tactical planning that is aligned with the institutional strategic planning or the Institutional Development Plan (IDP). Course coordinators, such as academic managers, should play this tactical role, thereby linking the guidelines set out in the strategic plans defined by senior management and the operational field. It is not intended to neglect the complexity of the proposal as it was conceived. On the contrary, as stated by Rué [18], this structure model requires investments of time and considerable involvement of the actors, in a process of reflection on the phenomenon and constant measurement and analysis of the results obtained.

Fact is that the academic management, viewed from this perspective, needs reformulation in its implementation processes, especially with regard to control, in order to build formal channels for measuring the results of the implemented 
model, thus generating conditions for feedback the system and constantly improve it.

\section{Conclusion}

This study aimed to investigate the critical perception about the Pedagogical Course Project (PCP) of the Administration Course of UFSCar - Natural Science Center, from the perspective of the actors most directly involved with this instrument.

As it is a methodology still under consolidation, of innovative character, it is observed that there are many points that need to be adjusted. However, it is emphasized that these pedagogical questions, in view of the challenge of implementing, executing and coordinating a teaching methodology with these characteristics, require a collective effort, with management based mainly on a systemic view, which sees not only its most various actors, the uniqueness of their specificities, but also the inevitable and complex relationship of interdependence and interaction of the parties.

There is an urgent need for greater emphasis on the dissemination of this instrument within the academic community. Nevertheless, the functionality and consolidation of the methodology proposed by PCP require from all actors involved an academic management effort with clear objectives, based on a functional agenda, built and practiced in several hands.

In short, there is a great deal of enthusiasm, commitment and commitment from most (if not all) of the actors involved to strive to achieve the desired goal: the training of a professional with a not strictly academic but more than that is, a professional with the technical, human and, at a higher level, conceptual skills.

Among others, a limitation of this study was the number of actors surveyed, circumscribed to five. Although they are the most directly related to the course management, it is possible, in a next step, to increase the number of research subjects, thus involving students and teachers from other courses, considering that all, with small variations in certain specificities, adopt the same methodology.

Thus, as a future research agenda, it is recommended to expand the number of respondents, in addition to inserting other variables that can be listed from the Pedagogical Course Project (PCP) of the other courses, comparing them with the Development Plan Institutional (DPI).

Finally, this paper can serve as a discussion text for the coordinators of the Business Administration courses, in particular, and other courses in general.

\section{References}

[1] Silva, FCT. (2008). Desenhando a cultura escolar: ensino aprendizagem e deficiência mental nas salas de recursos e nas salas comuns. In: Bueno, JGS., Mendes, GML., Santos, RA. (Orgs.). Deficiência e escolarização: novas perspectivas de análise. Araraquara: Junqueira \& Marin; Brasília: CAPES, 1: 67-108.
[2] Egorshin, AT., Abliazova, NO. \& Gus'kova, IV. (2007). Higher Economic Education in Russia, 1990-2025. Russian Education and Society, 49 (10): 30-52. DOI 10.2753/RES1060-9393491002.

[3] Galbraith, JK. (1976). A sociedade justa: uma perspectiva humana. Rio de Janeiro: Campus.

[4] Drucker, PF. (1974). Uma era de descontinuidades. Rio de Janeiro: Zahar.

[5] Colossi, N., Consentino, A. \& Queiroz, EG. (2001). Mudanças no contexto do ensino superior no Brasil: uma tendência ao ensino colaborativo. Revista FAE, Curitiba, 4 (1): 49-58.

[6] Popkewitz, T. (1998). Struggling for the Soul - the politics of schooling and the construction of the teacher. New York; London: Teachers College Press.

[7] Forquin, JC. (1993). Escola e cultura: as bases sociais e epistemológicas do conhecimento escolar. Porto Alegre: Artes Médicas.

[8] Segnini, LRP. (2000). Educação e trabalho: uma relação tão necessária quanto insuficiente. São Paulo em Perspectiva, 14 (2): $72-81$.

[9] Handfas, A. (2001). Considerações sobre as mudanças nos processos produtivos e a formação professional do trabalhador. In: Reunião Anual da Anped, 24, Caxambu-MG. Anais.... Disponível em: <http://www.anped.org.br>. Acesso em: 07/06/2016.

[10] Gonczi, A. (1996). Enfoques de educación y capacitación basada em competência: la experiencia australiana. In: Seminário Internacional de Formación Basada em Competencia Laboral: situación atual y perspectivas. Actas... México: Conocer/OIT, 69-77.

[11] Nunes, SC. \& Patrus-Pena, R. (2011). A pedagogia das competências em um Curso de Administração: o desafio de passer do projeto pedagógico à prática docente. Revista Brasileira de Gestão e Negócios, São Paulo, 13 (40): 281-299.

[12] Zabalza, MA. (2009). Retos de la escuela del siglo XXI: desarrollo del trabajo por competências. Revista HISTEDBR, 34: 3-18.

[13] Ropé, F. \& Tanguy, L. (Orgs.). (2003). Saberes e competências: o uso de tais noções na escola e na empresa. 4. ed. Campinas: Papirus.

[14] Perrenoud, P. (1999). Avaliação da excelência à regulação das aprendizagens: entre duas lógicas. Porto Alegre: Artmed.

[15] Burnier, S. (2001). Pedagogia das competências: conteúdos e métodos. Boletim Técnico Senac, 27 (3).

[16] Ching, HY., Silva, EC. \& Trentin, PH. (2014). Formação por competência: experiência na estruturação do Projeto Pedagógico de um curso de Administração. Administração: Ensino e Pesquisa, 15 (4): 661-691.

[17] Siqueira, L. \& Nunes, SC. (2011). Um olhar sobre o projeto pedagógico e as práticas docentes baseados na proposta de formação por competências. Administração: Ensino e Pesquisa, 12 (3): 415-445.

[18] Rué, J. A formação por meio de competências: possibilidades, limites e recursos. In: Rué, J., Almeida, MI., Arantes, VA. (Orgs.). (2009). Educação e competências: pontos e contrapontos. São Paulo: Summus. 
[19] Silva, FCT. (2016). Estudos comparados como método de pesquisa: a escrita de uma história curricular por documentos curriculares. Revista Brasileira de Educação, 21 (64): 209-224.

[20] Darnton, R. (2010). A questão dos livros: passado, presente e futuro. São Paulo: Companhia das Letras.

[21] Fischer, T., Waiandt, C. \& Fonseca, RL. (2011). A história do ensino em administração: contribuições teórico-metodológicas e uma proposta de agenda de pesquisa. Rio de Janeiro, Revista de Administração Pública, 45 (4): 911-939, jul. / ago.

[22] Brasil. Resolução $\mathrm{n}^{\circ}$ 4, de 13 de julho de 2005. Institui as Diretrizes Curriculares Nacionais do Curso de Graduação em Administração, bacharelado, e dá outras providências. Diário Oficial da União, Brasília, 19 de julho de 2005, Seção 1, p. 26.

[23] Zabala, A. \& Arnau, L. (2010). Como aprender e ensinar competências. Porto Alegre: ArtMed.

[24] Garcia, LAM. (2005). Competências e Habilidades: você sabe lidar com isso? Educação e Ciência On-line, Brasília: Universidade de Brasília. Disponível em: <http://uvnt. universidadevirtual.br/ciencias/002.htm $>$. Acesso em: 29 jun. 2016.

[25] Paulillo, LF. et al. (2015). Projeto Pedagógico do Curso de Bacharelado em Administração com Linha de Formação em Sistemas Agroindustriais. São Carlos. Disponível em: <http:// www.lagoadosino.ufscar.br/cursos/ppcs/PPC_ADMINISTRA CAO_12_2015.pdf $>$. Acesso em: 26 set 2019.

[26] Veiga, IPA. (2003). Inovações e Projeto Político-Pedagógico: uma relação regulatória ou emancipatória? Caderno Cedes, 23 (61): 267-281.

[27] Miller, TL., Wesley, CL. \& Williams, DE. (2012). Educating the minds of caring hearts: comparing the views of practitioners and educators on the importance of social entrepreneurship competencies. Academy of Management Learning \& Education, 11 (3): 349-370.

[28] Fischer, T. (2010). A perduração de um mestre e uma agenda de pesquisa na educação de administração: artesanato de si, memória dos outros e legados de ensino. Revista Organizações \& Sociedade, Salvador, 17 (52): 209-219, jan. / mar.

[29] Zabala, A. (1998). A prática educativa: como ensinar. Porto Alegre: Art Med.

[30] Silva, GB. \& Felicetti, VL. (2014). Habilidades e competências na prática docente: perspectivas a partir de situações-problema. Educação Por Escrito, Porto Alegre, 5 (1): 17-29, jan. / jun.

[31] Abreu, MC. \& Masseto, MT. (1996). O professor universitário em sala de aula: prática e princípios teóricos. São Paulo: MG Editores Associados.

[32] Castells, M. (1999). A Sociedade em rede. São Paulo: Paz e Terra.

[33] Veen, W. \& Vrakking, B. (2009). Homo Zappiens: educando na era digital. Porto Alegre: Artmed.

[34] Kanuka, H. (2013). Using blended learning strategies to address teaching development needs: How does Canada compare? The Canadian Journal of Higher Education, 43 (3): 19-35.

[35] Perrenoud, P. (1998). Construire des compétences, est-ce tourner le dos aux savoirs? Résonances. Mensuel de l'école valaisanne, 3: 3-7nov.

[36] Bertero, CO. (1995). Rumos da estratégia empresarial. RAE Light. 20-25.

[37] Brasil. (1997). Parâmetros Curriculares Nacionais: introdução aos parâmetros curriculares nacionais. Brasília: $\mathrm{MEC/SEF}$.

[38] Tanyel, F., Mitchell, MA. \& McAlum, HG. (1999). The skill set for success of new business school graduates: do prospective employers and university faculty agree? Journal of Education for Business, 75 (1): 33-37.

[39] Render, B., Stair Jr., RM. \& Hanna, ME. (2010). Análise quantitativa para Administração - com Excel ${ }^{\circledR}$ e POM-QM para Windows. 10. ed. Porto Alegre: Bookman.

[40] Gil, AC. (2010). Como elaborar projetos de pesquisa. São Paulo: Atlas.

[41] Brownell, P. (1995). Research methods in management accounting. Australia and New Zeland: Coopers \& Lybrand and Accounting Association of Australia and New Zealand.

[42] Bhattacherjee, A. (2012). Social Science Research: principles, methods, and practices. USF Tampa Bay Open Access Textbooks Collection, Book n. 3 .

[43] Firestone, WA. (1986). Meaning in method: The rhetoric of quantitative and qualitative research. Research for Better Schools, Inc., Philadelphia, Pa.

[44] Triviños, ANS. (1987). Introdução à pesquisa em Ciências Sociais: A pesquisa qualitativa em educação. São Paulo: Atlas.

[45] Eriksson, P. \& Kovalainen, A. (2008). Qualitative Methods in Business Research. London: Sage.

[46] Parker, L. (2014). Qualitative perspectives: through a methodological lens. Qualitative Research in Accounting \& Management, 11 (1): 13-28.

[47] Gil, AC. (1994). Métodos e técnicas de pesquisa social. 4. ed. São Paulo: Atlas.

[48] Eisenhardt, KM. (1989). Building theories from case study research. The Academy of Management Review, 14 (4): 532550.

[49] Yin, RK. (2005). Estudo de caso: planejamento e métodos. 3. ed. Porto Alegre: Bookman.

[50] Martins, GA. (2008). Estudo de caso: uma estratégia de pesquisa. 2. ed. São Paulo: Atlas.

[51] Gibbert, M. \& Ruigrok, W. (2010). The "what" and "how" of case study rigor: three strategies based on published work. Organizational Research Methods, 13 (4): 710-737.

[52] Bell, J. (2008). Projeto de pesquisa - guia para pesquisadores iniciantes em educação, saúde e ciências sociais. 4. ed. Porto Alegre: Artmed.

[53] Malhotra, NK. (1994). Marketing Research: An Applied Orientation. Journal of Marketing Research, 31 (1): 137-139.

[54] Malhotra, NK. (2015). Pesquisa de Marketing: uma orientação aplicada. 6. ed. Porto Alegre: Bookman.

[55] Hair Jr., JF., Babin, B., Money, AH. \& Samouel, P. (2005). Fundamentos de Métodos de Pesquisa em Administração. Porto Alegre: Bookman. 
[56] Blee, KM. \& Taylor, V. (2002). Semi-structured interviewing in social movement research. In: Klandermans, B., Staggenborg, S. (Eds.). Methods of social movement research. Minneapolis: University of Minnesota Press. 92-117.

[57] Godoi, CK. \& Mattos, PLCL. (2010). Entrevista qualitativa: instrumento de pesquisa e evento dialógico. In: Godoi, CK., Bandeira-de-Mello, R., Silva, AB. (Orgs.). Pesquisa qualitativa em estudos organizacionais: paradigmas, estratégias e métodos. 2. ed. São Paulo: Saraiva.

[58] Campbell, JL., Quincy, C., Osserman, J. \& Pedersen, OK. (2013). Coding in-depth semistructured interviews problems of unitization and intercoder reliability and agreement. Sociological Methods \& Research, 42: 294-320.

[59] Hair Jr. JF. et al. (2007). Research Methods for Business. England: John Wiley \& Sons.
[60] Hair Jr. JF. et al. (2015). Essentials of Business Research Methods. 2. ed. New York, USA, Routledge.

[61] Cooper, DR. \& Schindler, PS. (2016). Método de pesquisa em administração. 12. ed. Porto Alegre: AMGH.

[62] Yin, RK. (2016). Pesquisa qualitativa - do início ao fim. Porto Alegre: Penso.

[63] Bechker, HA. (1972). Observation by informants in institutional research. Quality \& Quantity, 6: 157-169.

[64] Vieira, AMDP. \& Filipak, ST. (2015). Avaliação da Educação Superior: limites e possibilidades do Núcleo Docente Estruturante. Revista Diálogo em Educação, Curitiba, 15 (44): 61-87, jan. / abr. 